\title{
Induction of vitellogenin-like lipoproteins in the mussel Aulacomya ater under exposure to $17 \beta$-estradiol
}

Inducción de lipoproteínas tipo vitelogenina en el mejillón Aulacomya ater expuesto a 17ß-estradiol

\author{
Luisa Saavedra',2, Maritza Leonardi, ${ }^{2,4}$, Violeta Morin ${ }^{3}$ and Renato A. Quiñones ${ }^{1,2}$
}

\author{
1'Department of Oceanography, Universidad de Concepción, Casilla 160-C, Concepción, Chile, 1saavedr@udec.cl \\ ${ }^{2}$ Programa de Investigación Marina de Excelencia (PIMEX), Universidad de Concepción, Casilla 160-C, Concepción, Chile \\ ${ }^{3}$ Department of Biochemistry and Molecular Biology, Faculty of Biological Sciences, Universidad de Concepción, Casilla \\ 160-C, Concepción, Chile \\ ${ }^{4}$ Facultad de Ciencias Biológicas, Universidad Nacional Andres Bello, Autopista Concepción, Talcahuano 7100, Chile
}

\begin{abstract}
Resumen.- El mejillón Aulacomya ater fue expuesto a diferentes concentraciones de $17 \beta$-estradiol (E2) (0, 1, $\left.100 \mu \mathrm{g} \mathrm{L}^{-1}\right)$ por 21 días y durante 4 periodos de muestreo, con el objeto de evaluar como reaccionan estos organismos ante la exposición a compuestos estrogénicos externos. Además, se inyectaron 2 concentraciones de $17 \beta$-estradiol $(0,5$ y 1 mmol) en el músculo abductor de 5 individuos. El efecto del E2 se determinó a través de la medición de los niveles de vitelogenina (Vg) en gónadas, utilizando el ensayo del fosfato alcalino lábil (ALP) y mediante el análisis histológico de las gónadas. Los resultados demuestran un incremento en los niveles de ALP para los machos expuestos a los menores niveles de E2, principalmente durante los primeros 4 días de exposición, indicando que la respuesta de la Vg al E2 es dependiente del tiempo. Se observaron algunas diferencias en los parámetros reproductivos (Índice gonadosomático y madurez) de machos y hembras expuestas y no expuestas a E2. Además, se encontraron claras diferencias en los niveles de ALP entre los sexos, siendo estos más elevados en las gónadas de los machos. No se detectaron respuestas en los niveles de $\mathrm{Vg}$ en hembras expuestas a las concentraciones experimentales de E2. Nuestros resultados sugieren que el ciclo reproductivo de $A$. ater podría ser alterado por la exposición a E2, lo que resulta relevante al considerar los recientes informes de altos niveles de E2 en los sedimentos de Chile centro-sur.
\end{abstract}

Palabras clave: Disrupción endocrina, estrógenos, ensayo del fosfato alcalino-lábil, bivalvos

\begin{abstract}
The mussel Aulacomya ater was exposed to $17 \beta$-estradiol (E2) $\left(0,1,100 \mu \mathrm{g} \mathrm{L}^{-1}\right)$ for 21 days with 4 sampling periods to evaluate how these organisms deal with exogenous estrogenic compounds. In addition, 2 concentrations of $17 \beta$-estradiol $(0.5,1 \mathrm{mmol})$ were injected into the abductor muscle of 5 individuals. The effects of E2 were determined by measuring the vitellogenin (Vg) levels with an alkaline labile phosphate (ALP) assay for gonads and using histological analyses. The results show an increment in ALP levels for males exposed to the lowest E2 levels, principally during the first 4 days of exposure, indicating that the response of Vg to E2 is time-dependent. Some differences were observed between the reproductive parameters (gonadosomatic index and maturity) of males and females exposed and unexposed to E2. Clear differences were also found in ALP levels between sexes, with the highest value occurring in male gonads. No response in Vg levels was detected in females after exposure to E2. Our results suggest that the reproductive cycle $A$. ater may be altered by E2 exposure, which is relevant considering recent reports of high levels of E2 in the sediments off south-central Chile.
\end{abstract}

Key words: Endocrine disruption, estrogens, Alkali-labile phosphate assay, bivalves

\section{INTRODUCTION}

Estrogens are hormones that play a major role in sexual differentiation, sex-gland development, and oocyte growth of most oviparous species (Wang et al. 2008); they also play an important role in bone maintenance, the cardiovascular system and the central nervous system (Janer 2005). These compounds may be of natural $[17 \beta-$ estradiol (E2), estrone (E1), estriol (E3)] or synthetic [17ßethynylestradiol (EE2), and diethylstilbestrol (DES)] origin; natural estrogens are principally synthesized and excreted by the ovary. At present, both types of estrogens are released into the environment due mainly to the use of estrogen-replacement therapy and via livestock manure (Chen et al. 2010). This has become an important area of research, given that estrogens are currently recognized as the most potent endocrine disrupting compounds (Caliman \& Gaverilescu 2009). Estrogens have the potential to interact with the estrogen-signaling pathway, leading to the increased production of the egg-yolk protein precursor vitellogenin $(\mathrm{Vg})$, to the feminization of the reproductive duct, and to intersex in fish (Thorpe et al. 2003, Wester et al. 2004) and bivalves (Gagné et al. 2001). 
Estrogen-disrupting compounds include E2, the most potent natural estrogenic hormone naturally present in the environment. This compound is of concern since it can reach aquatic environments through domestic effluents (Gagné et al. 2005, 2010), livestock waste (Chen et al. 2010), and agricultural runoff (Lee et al. 2007). Different studies have shown that E2 can induce Vg at very low concentrations $\left(1 \mathrm{ng} \mathrm{L}^{-1}\right)$ in male trout (Hansen et al. 1998, Tremblay \& Van der Kraak 1998). Moreover, due to its high estrogenic potential E2 has often been used as 'a model estrogenic compound' in studies that assess the effects of xenoestrogenic compounds on aquatic organisms (Janer et al. 2005).

The presence of E2 and other estrogens in aquatic environments has led to increasing research on the impact of these compounds on bivalves, which filter large quantities of water and increase their exposure to contaminants (Gagné et al. 2004). Furthermore, these organisms are relevant for analysis given their abundance in nature, their ecological importance, and their use as bioindicators in monitoring water pollution (Ketata et al. 2008).

Though little is known about invertebrate endocrinology, several studies have shown that the main effect of E2 on the reproductive system of bivalve mollusks is the increase of Vg levels (Li et al. 1998, Blaise et al. 1999, Matozzo \& Marin 2008, Gagné et al. 2010, 2011, Moura-Costa et al. 2010). The production of Vg, the major precursor of the egg-yolk proteins (vitellins), is the main indicator used to determine endocrine disruption in oviparous organisms (Wallace 1985). It is the major energy-rich glycolipophosphoprotein for developing embryos in vertebrates and invertebrates. Vg levels generally increase in sexually mature females, but are lower or undetectable in juveniles and males, probably due to low levels of estrogens in plasma (Wallace 1985). However, males have a functional, silent Vg gene that may be activated by (xeno)-estrogens (Flouriot et al. 1995). In bivalves, $\mathrm{Vg}$ is synthesized in the vesicular connective tissue of the female gonads, transported to the oocytes by hemolymph and then incorporated in developing oocytes by pinocytosis (Matozzo \& Marin 2005). This process is induced and regulated by estrogens (Li et al. 1998) and appears to be susceptible to endocrinedisrupting compounds (EDCs), since bivalves respond to exposure to estrogen and xeno-estrogens by increasing levels of $\mathrm{Vg}$. An antibody for mussel Vg is not commercially available at present, however $\mathrm{Vg}$ levels can be measured through an indirect assay termed alkali-labile phosphate assay (ALP), based on the determination of labile phosphates released by $\mathrm{Vg}$ after hydrolysis with alkali (Blaise et al. 1999). This method offers a simple cost-effective biomarker of endocrine disruption in mussels (Porte et al. 2006). Some studies of bivalves have used this approach, finding that $\mathrm{Vg}$ seems to be relatively sensitive to estrogen exposure (Gagné et al. 2001, Aarab et al. 2006, Matozzo et al. 2008) and that endocrine disruption occurs after exposure to estrogenic compounds and urban effluents (Gagné et al. 2001, Quinn et al. 2004, Ortiz-Zaragoitia \& Cajaraville 2006).

Aulacomya ater (Molina, 1782) is an economically important mussel inhabiting the shallow waters of Chile's south-central coast, forming extensive beds on rocky substrates. It is a gonochoric species found in South Africa (Griffiths 1977) and South America, from Callao (Peru) to the Strait of Magellan (Chile) in the Pacific, and from southern Brazil, along Argentina, to the Falkland Islands in the Atlantic (Jaramillo \& Navarro 1995). Little is known about the life cycle of A. ater in south-central Chile, but Jaramillo \& Navarro (1995) showed a continuous gamete release over several months during the year for individuals from southern Chile. They observed clear peaks of pre-spawning stages in April, August, November and February. The spawning stage in females peaked in July and December, but males released gametes from May to January. Also continuous spawning was found from June to January, related to fluctuations in phytoplankton levels.

The coast of south-central Chile, where shoals of this species are frequently found, is strongly influenced by domestic and industrial waste coming from coastal cities and river runoff (Rudolph et al. 2002). This may lead to significant sediment contamination by steroid estrogens, principally released from human sewage, with levels of E2 and 17ß-ethinylestradiol in south-central Chile between 0.06 and $4.61 \mathrm{ng} \mathrm{g}^{-1}$ dry weight ( $\mathrm{dw}$ ) and 0.06 to $16.81 \mathrm{ng}$ $\mathrm{g}^{-1} \mathrm{dw}$, respectively (Bertin et al. 2011). Therefore, the main goal of this study was to investigate the estrogenic effect of the natural estrogen E2 on the bivalve A. ater through the induction of Vg-like proteins and histological observations.

\section{Materials AND METHODS}

\section{Mussel COLLECTION AND MAINTENANCE}

Specimens of Aulacomya ater (5.5-6.5 cm shell length) were collected from Coliumo Bay (Chile; $36^{\circ} 31^{\prime} \mathrm{S} ; 7^{\circ} 55^{\prime} \mathrm{W}$ ) 
a small and shallow bay commonly used as a control site in environmental studies due to its low anthropogenic activity (Palma et al. 2007, Aguirre- Martinez et al. 2009, Srain \& Rudolph 2010). The samples were obtained during December 2009, and acclimatized in the laboratory for 7 days before exposure to E2. Mussels were maintained in $30 \mathrm{~L}$ polystyrene aquaria provided with aerated seawater at a salinity of $35 \pm 1$ and temperature of $11 \pm 0.3^{\circ} \mathrm{C}$, under a $12 \mathrm{hlight} / 12 \mathrm{~h}$ dark cycle. The water was changed every day, at which point the mussels were fed a mixture of the microalgae (Isochrysis galbana and Chaetoceros muelleri).

\section{EXPOSURE EXPERIMENTS AND SAMPLING}

\section{EXPOSURE TO E2 DISSOLVED IN WATER}

During a 21 day exposure period, mussels $(n=27)$ were exposed to the following concentrations of E2 (SigmaAldrich): E2-1 $=1 \mu \mathrm{g} \mathrm{L}-1$, E2-100 $=100 \mu \mathrm{g} \mathrm{L}{ }^{-1}$. The lower concentration was chosen on the basis of data available in the literature concerning E2 estrogenicity (Janer et al. 2004, Matozzo \& Marin 2008), while the higher was selected as a saturated concentration. A stock solution of E2 was prepared in acetone (Matozzo \& Marin 2008) and stored at room temperature for the duration of the experiments. Working solutions were prepared by diluting the stock solution into the microalgae feed mixture. For the control, acetone was added at the same concentration $\left(20 \mu \mathrm{L} \mathrm{L}^{-1}\right)$ used in both treatments. The acetone solvent was diluted 20,000 times in the tanks. Of the 27 mussels allocated per treatment, 6 were sampled from each tank at $0,90,282$ and $474 \mathrm{~h}$.

Six replicates were sampled per treatment group and the following biometric data were recorded: weight $(\mathrm{g})$, total shell length $(\mathrm{cm})$, whole soft and gonad tissue weights $(\mathrm{g})$, condition index (CI = wet weight of soft tissues/ wet weight of shell) and gonadosomatic index (GSI = gonad wet weight/ total tissue wet weight). The sex was first determined visually, since females have black colored gonads while in males they are yellowish, and then with histological analysis. The gonads of each individual were sectioned in two parts: one for the $\mathrm{Vg}$ analysis described below and the other for histology.

\section{EXPOSURE TO E2 VIA INJECTION}

Five A. ater specimens were injected in the anterior abductor muscle with $0.5 \mu$ mole of E2 and 5 specimens with $1 \mu$ mole of E2; both concentrations were chosen according to Gagné et al. (2001). The solvent dimethyl sulfoxide (DMSO, 100\%) was selected to dissolve E2 (Blaise et al. 1999, Gagné et al. 2001). In the experiment, $25 \mu \mathrm{l}$ of the substance per $40 \mathrm{~g}$ of total body plus shell weight were injected into each mussel. Control mussels received only the solvent $(\mathrm{n}=5 ; 25 \mu \mathrm{l}$ of DMSO per $40 \mathrm{~g}$ of total body plus shell weight). After injection, the mussels were incubated for $96 \mathrm{~h}$ at $11 \pm 0.3^{\circ} \mathrm{C}$ in aerated seawater. At the end of the incubation period the mussels were sampled as described above.

\section{VITELLOGENIN DETERMINATION}

An indirect quantitative method was used to establish $\mathrm{Vg}$ levels in the gonads of A. ater, through ALP.

Gonad tissues were homogenized in $25 \mathrm{mM}$ Hepes$\mathrm{NaOH}, \mathrm{pH} 7.4$, containing $125 \mathrm{mM} \mathrm{NaCl}, 1 \mathrm{mM}$ dithiothreitol and $1 \mathrm{mM}$ EDTA at $4^{\circ} \mathrm{C}$. The homogenate was centrifuged at $12000 \mathrm{x} g$ for $20 \mathrm{~min}$ at $4^{\circ} \mathrm{C}$. The supernatant (S12) was carefully removed from the pellet and kept at $-80^{\circ} \mathrm{C}$ until analysis.

$\mathrm{Vg}$ levels in gonad homogenate extracts were determined using the indirect alkali labile phosphate method (ALP) (Blaise et al. 1999) modified by Gagné et al. (2003) and Ortiz-Zaragoitia \& Cajaraville (2006). A subsample of the supernatant was adjusted to $35 \%$ acetone and centrifuged at $10,000 \times \mathrm{g}$ for $5 \mathrm{~min}$. The pellet was dissolved in $200 \mathrm{ml}$ of $\mathrm{NaOH} 1 \mathrm{M}$ at $60^{\circ} \mathrm{C}$ for $30 \mathrm{~min}$. Inorganic phosphate levels were determined using the phosphomolybdenum method (Stanton 1968). A subsample of $100 \mu \mathrm{l}$ was mixed with $25 \mu \mathrm{l}$ trichloroacetic acid, $600 \mu \mathrm{l}$ ultrapure water, $125 \mu 1$ molybdenum reagent $(0.02 \mathrm{M}$ ammonium molybdate tetrahydrate and $5.25 \mathrm{M} \mathrm{H}_{2} \mathrm{SO}_{4}$ solution), and $125 \mu \mathrm{l}$ ascorbate (Sigma-Aldrich) (Francois Gagné pers. comm.). After incubating for $20 \mathrm{~min}$ at $37^{\circ} \mathrm{C}$, the absorbance was measured at $660 \mathrm{~nm}$ using a Shimadzu UV-1603 spectrophotometer. A series of $\mathrm{KH}_{2} \mathrm{PO}_{4}$ concentrations were used for the inorganic phosphate standard curve. ALP levels in gonads are given as $\mu \mathrm{g}$ phosphate $\mathrm{mg}^{-1}$ protein. Total protein in the supernatants was determined according to Bradford (1976).

\section{GONAD HISTOLOGY}

Gonads were fixed in $10 \%$ neutral buffered formalin, dehydrated through increasing concentrations of ethanol and embedded in paraffin. Serial sections ( $5 \mu \mathrm{m}$ thickness) were cut and stained with hematoxylin and eosin. Histological alterations (hemocytic aggregates, 
macrophage aggregates (GMA), hemocytes, fibrosis and atresic oocytes) and developmental stages were determined for each animal. Five developmental stages were determined in mussels according to Gauthier-Clerc et al. (2006): phase I= undifferentiated (pre-vitellogenesis/ spermatogenesis); phase II = development (early

a

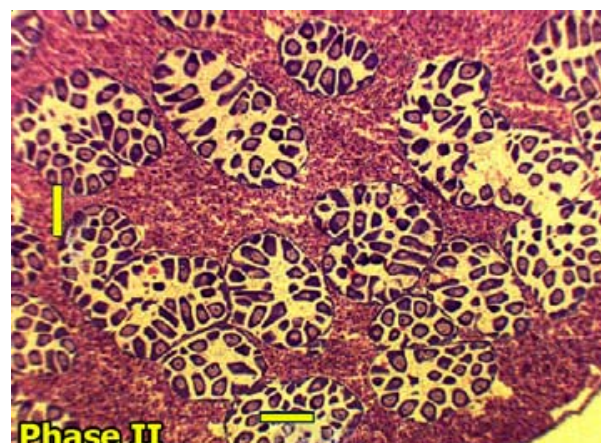

\section{Rhase in sog.}
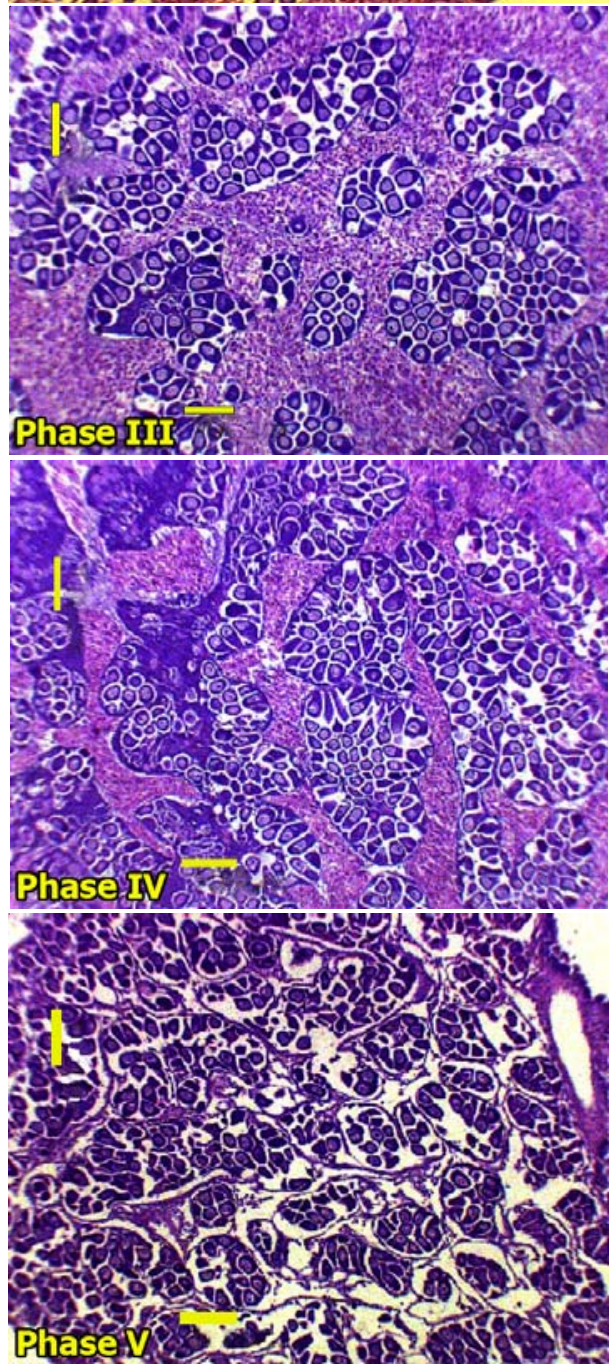

vitellogenesis/spermatogenesis); phase III = mature gonad (late vitellogenesis/spermatogenesis); phase IV = spawning gonad; and phase $\mathrm{V}=$ post-spawning gonad (Fig. 1). The prevalence of pathologies was examined with an optical microscope $(4 \mathrm{x}, 10 \mathrm{x}, 40 \mathrm{x})$.

b
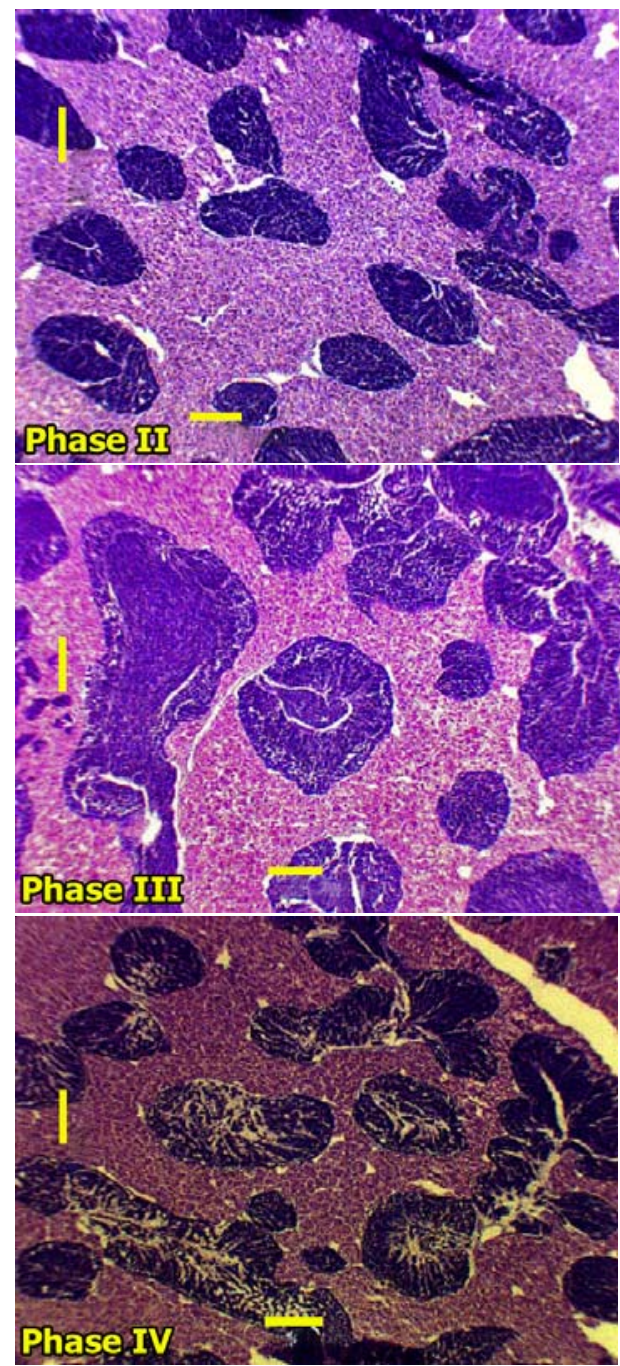

Figure 1. Light micrographs of gonads from experimental mussels showing development stages of (a) females and (b) males. Scale bar: $100 \mu \mathrm{m} /$ Cortes microscópicos de gónadas de los moluscos experimentales, mostrando las etapas de desarrollo de (a) hembras y (b) machos. Escala: $100 \mu \mathrm{m}$ 


\section{STATISTICAL ANALYSIS}

Statistical analyses were performed with the software GraphPad Prism ${ }^{\circledR}$ (Version 4). Data were checked for normality using the Kolmogorov-Smirnov (KS) test. A factorial two-factor analysis of variance, with time and treatments as major factors, followed by a Tukey post hoc test was used to test for significant differences in ALP concentration. This analysis was done separately for males and females. Furthermore, to test for significant differences in the ALP concentration between sexes in each treatment a two-factor analysis of variance was used with time and sex as major factors. Significance was established at $P<0.05$. The results are expressed as mean \pm standard error.
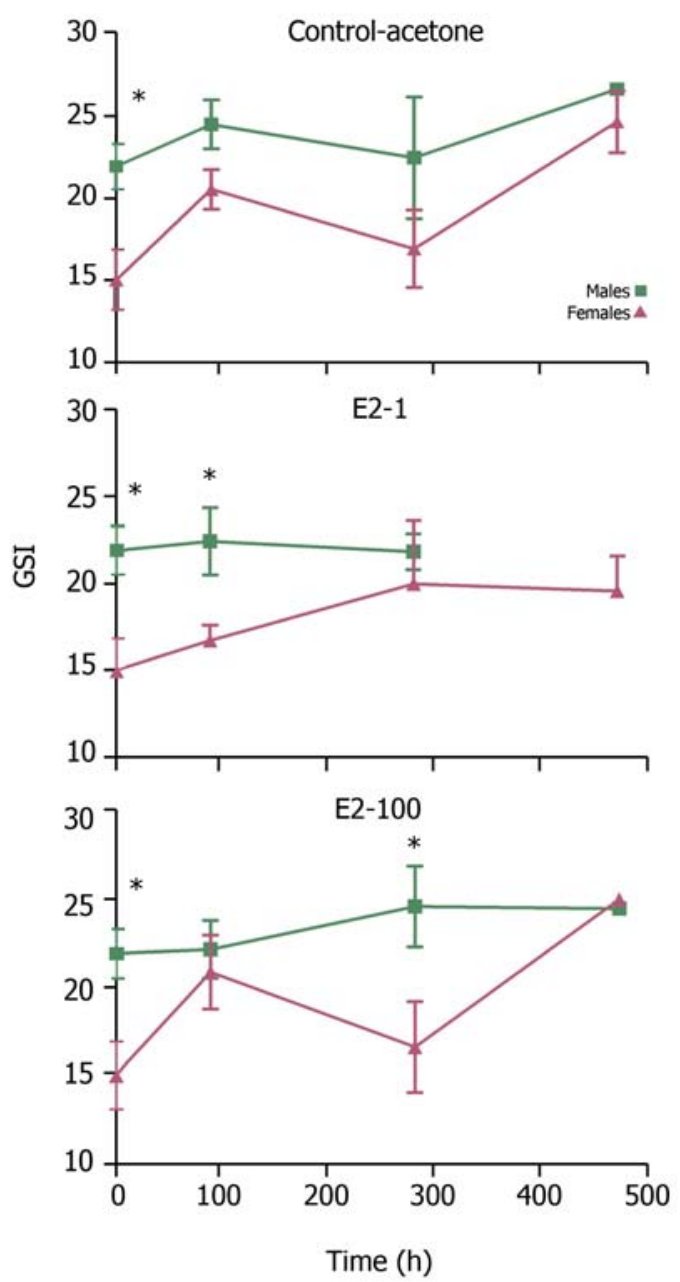

Figure 2. Gonadosomatic index (GSI) variation with time, for males and females of (a) control-acetone, (b) E2-1 (1 $\left.\mu \mathrm{g} \mathrm{L}^{-1}\right)$ and (c) E2-100 $\left(100 \mu \mathrm{g} \mathrm{L}^{-1}\right)$ treatments. ${ }^{*}$ significant differences between sexes $(P$ $<0.05$ ) / Variación del índice gonadosomático (IGS) en el tiempo, para los machos y hembras del (a) control-acetona, (b) tratamiento con E2-1 $\left(1 \mu \mathrm{g} \mathrm{L}^{-1}\right)$ y (c) tratamiento con E2-100 (100 $\left.\mu \mathrm{g} \mathrm{L}^{-1}\right) .{ }^{*}$ Estadísticamente significativo $(P<0,05)$

\section{Results}

Organisms exposed to the 2 treatments showed a similar gonadosomatic index (GSI), without significant changes with time of exposure. However, the GSI of males and females differed, especially in the acetone control and during the first days of exposure (Fig. 2). According to the histological analyses, most individuals were in developmental stage II, III, and IV (Figs. 1 and 3). Males presented a less advanced development stage than females, which was confirmed by histological analyses (Fig. 3).

$\mathrm{Vg}$ concentrations obtained by ALP showed significant differences between males and females (Fig. 4), especially for the group subjected to the treatment with the lower E2 concentration (1 $\left.\mathrm{gg} \mathrm{L}^{-1}\right)$ (Fig. $\left.4 \mathrm{~b}\right)$. Males had higher ALP levels, especially during the first sampling period (90 h). In the treatment with the higher E2 concentration (E2100), males and females showed similar ALP levels.

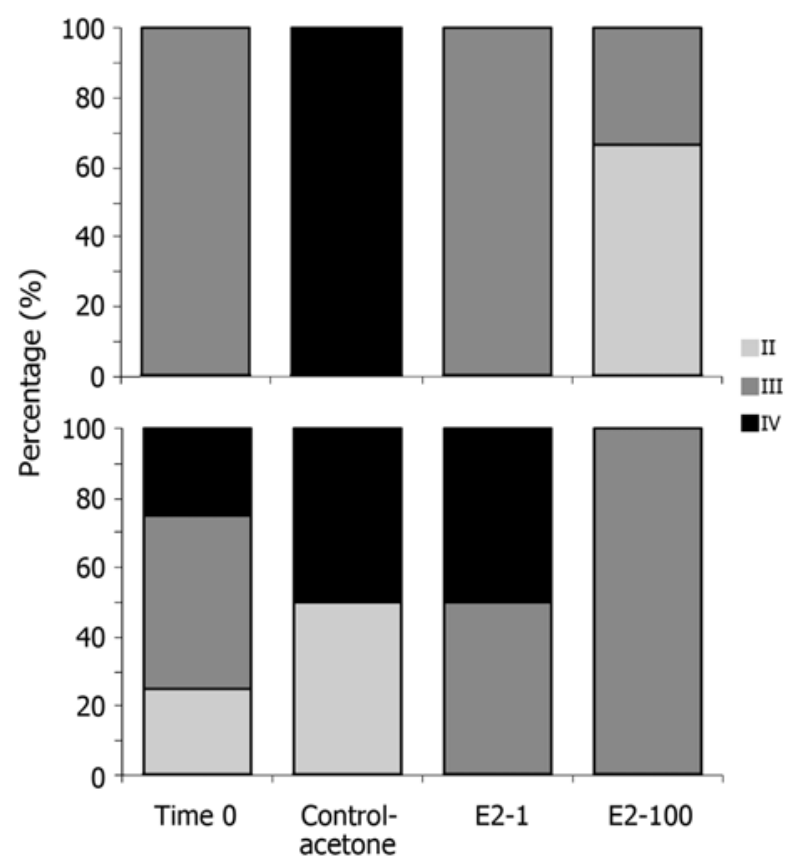

Figure 3. Percentages of mussels at each gonad developmental stage: (a) females and (b) males. There was only one female in stage $V$ and it was not included in this figure / Porcentaje de moluscos en cada etapa de desarrollo: (a) hembras y (b) machos. Sólo se encontró una hembra en estado $V$ por lo que no se incluyó en esta figura 


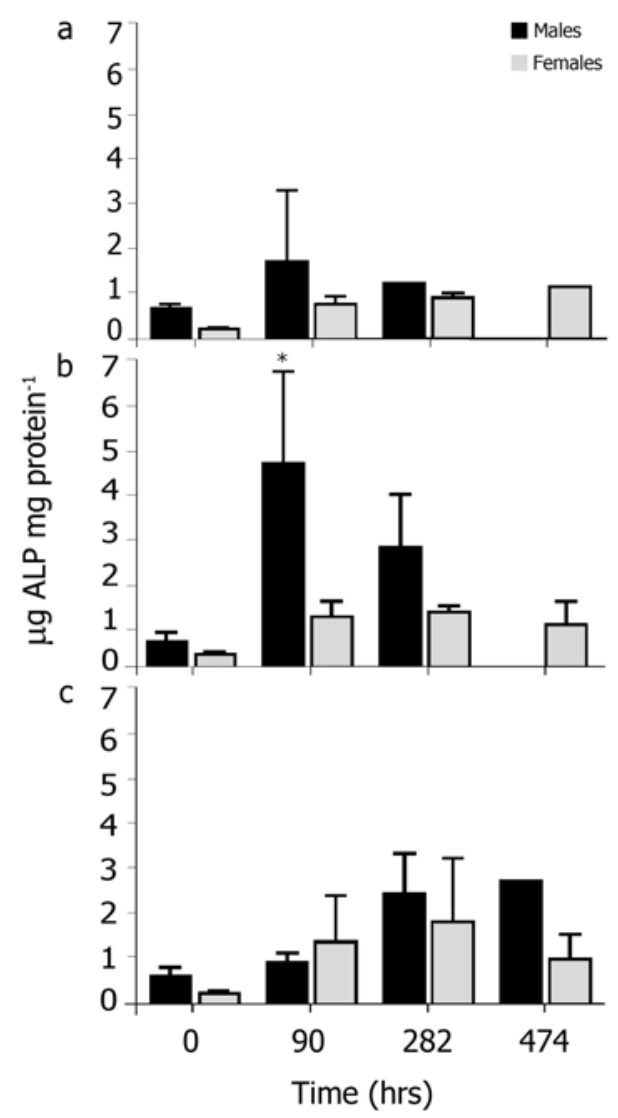

Figure 4. Differences in gonad ALP levels between males and females of $A$. ater exposed to (a) control acetone, (b) $1 \mu \mathrm{g} \mathrm{L}^{-1}$ (E2-1), (c) $100 \mu \mathrm{g} \mathrm{L}^{-1}$ (E2-100). *significant differences between sexes $(P<$ 0.05) / Diferencias entre los niveles de ALP de gónadas de machos y hembras de $A$. ater expuestos a (a) control-acetona, (b) $1 \mu \mathrm{g} \mathrm{L} \mathrm{L}^{-1}$ (E2-1), (c) $100 \mu \mathrm{g} \mathrm{L}^{-1}$ (E2-100). * diferencias significativas entre sexos $(P<0,05)$

Due to the different concentrations of ALP between sexes, we compared the different treatments for males and females separately (Fig. 5). In the case of the females, the time is the main factor explaining the observed differences in ALP concentration, and no significant differences were found between treatments exposed to the 2 experimental concentrations of E2. In males, time was also the main factor but the post hoc test showed, for the second sampling interval $(90 \mathrm{~h})$, a significant higher ALP level in the treatment with lower E2 concentration $(P<0.05)$ (Fig. 5b). After this initial period, ALP levels dropped to concentrations similar to the control. In addition, a trend to increase ALP concentration over time was observed in the treatment with high concentration of E2 $\left(100 \mu \mathrm{g} \mathrm{L}^{-1}\right)$ (Fig. 5b).

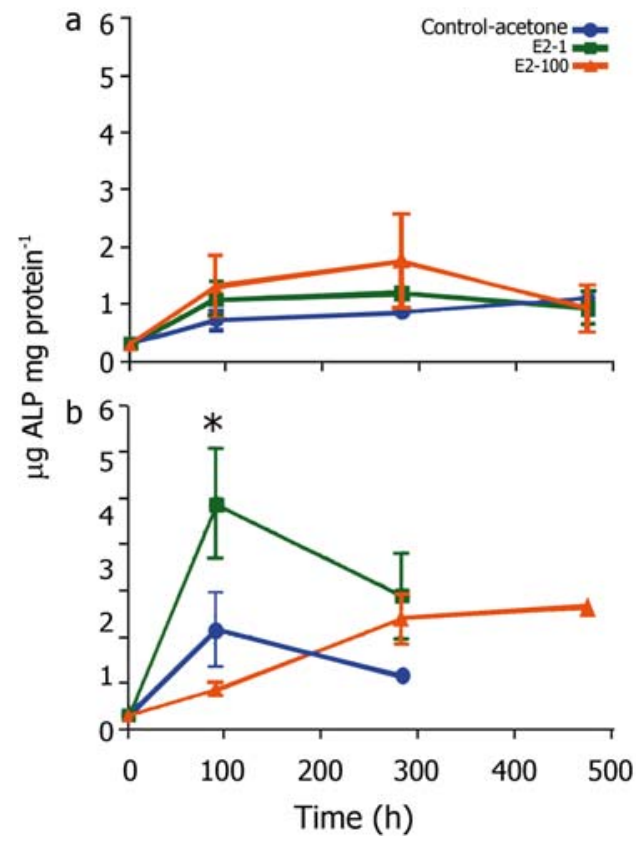

Figure 5. Relation between ALP levels and time, showing differences between treatments and control for (a) females and (b) males. *: significant differences between treatments $(P<0.05) /$ Relación entre los niveles de ALP y el tiempo, mostrando las diferencias entre los tratamientos y el control para (a) hembras y (b) machos. *: diferencias significativas entre tratamientos $(P<0,05)$

The induction assay using the direct injection of 2 E2 concentrations was impaired due to the fact that it was not possible to know in advance the sex of the specimen, and accordingly, the sex proportion in the experiment was not adequate (Table 1). Nevertheless, we have reported the results in Table 1 because they also show differences in ALP concentration between males and females (Fig. 6). On the average, the concentration of $\mathrm{Vg}$ found was higher in males than in females (Fig. 6), particularly in males exposed to the lower E2 concentration.

Table 1. Gender segregated average ALP concentrations ( $\mu$ g ALP $\mathrm{mg}$ protein $^{-1}$ ) for induction experiments / Promedio de las concentraciones de ALP ( $\mu$ g ALP mg protein ${ }^{-1}$ ) separadas por sexos, para los experimentos de inducción

\begin{tabular}{lccccc}
\cline { 2 - 3 } & \multicolumn{2}{c}{ Females } & & \multicolumn{2}{c}{ Males } \\
\cline { 2 - 3 } \cline { 5 - 6 } & $\mathrm{n}$ & Mean & & $\mathrm{n}$ & Mean \\
\hline Control DMSO & 3 & $0.055 \pm 0.005$ & & 0 & - \\
E2-0.5 & 0 & - & 3 & $5.769 \pm 5.080$ \\
E2-1 & 3 & $0.299 \pm 0.074$ & 1 & 2.085 \\
Total Mean & 6 & $0.177 \pm 0.142$ & 4 & $4.541 \pm 4.200$ \\
\hline
\end{tabular}




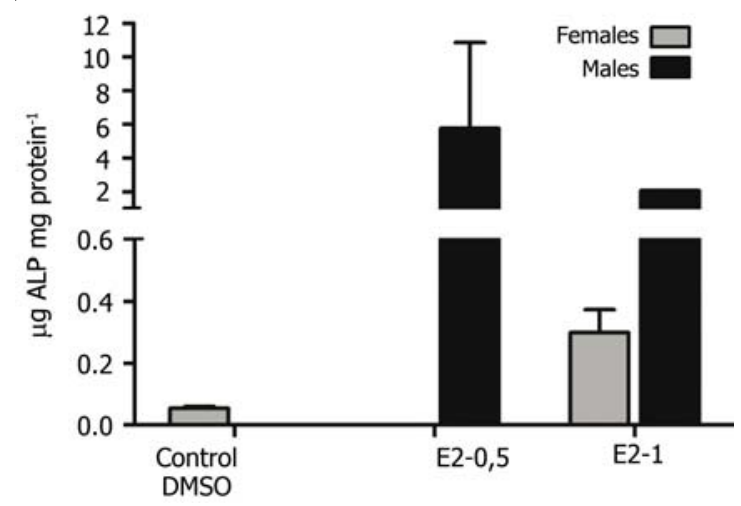

Figure 6. ALP levels in gonads of directly induced (injected) organisms with 0.5 and $\mathbf{1} \mu \mathrm{mol}$ E2 and DMSO as control, showing differences between the sexes / Niveles de ALP en gónadas de organismos inducidos directamente (inyectados) con 0,5 y $1 \mu \mathrm{mol}$ E2 y DMSO como control, mostrando las diferencias entre los sexos

Figure 7 shows the most common pathologies found in this experiment, principally hemocytic aggregates, macrophage aggregates (GMA), hemocytes, fibrosis and atresic oocytes. Again there was a clear difference between sexes, with more pathology found in males. However, the presence of atresic oocytes in all females is remarkable. No significant differences were found between the treatments and the control for either sex.

\section{Discussion}

With regard to the general condition of the organisms, both the condition and the gonadosomatic indices failed to show important differences between the treatments. Nonetheless, we noted a much higher GSI in males in comparison to females in all treatments as well as in the control, which is consistent with the high levels of atresic oocytes observed in females. A high percentage of females with atresic gonad follicles was also reported in Mytilus galloprovincialis by Suárez Alonso et al. (2007), indicating the reabsorption of oocytes, either due to lack of favorable environmental conditions (temperature, food) or to the end of the gonadal cycle (summer). In the sampling period (December) the development stages were different for both sexes, with males presenting a less advanced development stage than females. This is coherent with the reproductive cycle of $A$. ater described by Jaramillo \& Navarro (1995), with females having a peak of gamete release between July and December whereas males release gametes continuously between May and January.

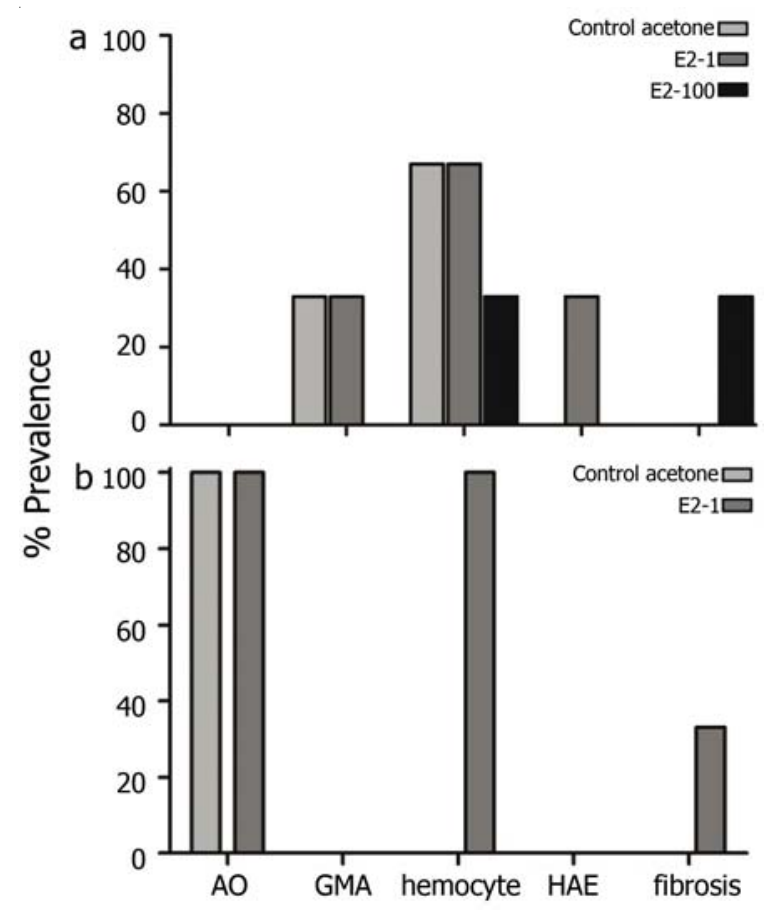

Figure 7. Prevalence of pathologies in gonads of $A$. ater exposed to 17 $\beta$-estradiol: (a) males and (b) females. Values are averages over sampling periods. HAE: Hemocytic aggregates, GMA: Macrophage aggregates / Prevalencia de patologías encontradas en gónadas de $A$. ater expuesta a $17 \beta$-estradiol: (a) machos y (b) hembras. Los valores son promedios de los periodos de muestreo. HAE: agregación hemolítica, GMA: agregación macrófaga

In this study we used the indirect method for determining Vg-like proteins (ALP) due to the lack of antibodies against specific $\mathrm{Vg}$ for this species and for mollusks in general (Blaise et al. 1999). Using this method we were able to detect important differences in ALP level between males and females. We noted a significant increase of ALP in males exposed to the lower E2 concentration, mainly during the first 4 days of exposure $(90 \mathrm{~h})$. This suggests that the response of $\mathrm{Vg}$ to E2 is time-dependent, and thus it is a factor that should be taken into account in bivalve endocrine disruption studies. Most studies of Vg induction by E2 in mollusks have only considered one incubation period (Blaise et al. 1999, Gagné et al. 2001, Janer et al. 2004), thereby omitting the time-dependent response to the endocrine disruptor. One exception is the study of Matozzo \& Marin (2008), which included sampling during 2 different periods of the induction experiment (at 7 and 14 days), finding differences in the responses of $\mathrm{Vg}$ to the EDCs. These temporal variations may be due to mechanisms of 
regulation of free steroid-levels (e.g., conjugation rates and esterification), which could influence the decline of $\mathrm{Vg}$ over time. These mechanisms play an important role in the endocrine homeostasis of mollusks (Janer 2005, Lavado et al. 2006).

On the other hand, Vg only increased significantly with the lower E2 concentration $\left(1 \mu \mathrm{g} \mathrm{L}^{-1}\right)$, in agreement with recent studies that propose that estrogens generate more effects at low concentrations (non-monotonic dose response) in mammals and various other species (Welshons et al. 2003, 2006, Weltje et al. 2005). This same effect was observed by Matozzo \& Marin (2008) in clams (Tapes phillipinarum) exposed to different E2 concentrations and by Ciocan et al. (2010) concerning the expression of Vg mRNA in Mytilus edulis. The response to low E2 concentrations may be due to the fact that this compound behaves like an endogenous steroid and can regulate physiological functions, whereas high concentrations of E2 significantly increase the activity of inactivation mechanisms for excessive E2 (palmitoylCoA; estradiol transferases) (Janer et al. 2005). However, it is important to note that the lower E2 experimental concentration used in the present study is very high compared to ambient levels (about $0.02 \mu \mathrm{g} \mathrm{L}^{-1}$ in sediments), and therefore we cannot discard induction of $\mathrm{Vg}$ when A. ater is exposed to E2 at environmental concentrations lower than $1 \mu \mathrm{g} \mathrm{L} \mathrm{L}^{-1}$.

The significant difference found between the ALP levels of males and females, mainly in the control and in the treatment with the lower E2 concentration, leads us to suggest the following hypotheses: (i) the higher level of ALP in males is explained by the lower levels of proteins in their gonads because they are in an earlier stage of gamete development, and (ii) males were induced by endocrine disruptors present in the natural environment. Other studies also reported the same situation: Matozzo \& Marin (2005) for the clam Tapes philippinarum, Hashimoto et al. (2000) for male flounder Pleuronectes yokohamae, and Pampanin et al. (2005) for Mytilus galloprovincialis. In the last study the authors suggested that the presence of chemicals with estrogenic effect was probably able to induce the expression of the Vg-like proteins in males, whereas in females, where this protein is normally expressed during gametogenesis, the parallel process could be masked. Our hypothesis of a natural environmental vitellogenin induction in males of $A$. ater is supported by the presence of high concentrations of E2 and ethinyl-estradiol (EE2) in the coastal sediments off south-central Chile (Bertin et al. 2011). The presence of EDCs in the coastal environment such as polyaromatic hydrocarbons (PAHs) and alkylphenols are known to produce in mussels high prevalence of oocyte athresia and low ALP levels in females, and high ALP levels in males (Ortiz-Zaragoitia \& Cajaraville 2003'). In our experiments we also found high levels of oocyte athresia including those animals that were not exposed to E2. Unfortunately, to the best of our knowledge, there is no information available about the natural level of this pathology in A. ater populations.

In conclusion, the results of this study show that males and females of A. ater respond differently to E2 exposure. $\mathrm{Vg}$ levels increased in A. ater males exposed to low E2 concentrations, but only in the first days of exposure, thereby suggesting that the mechanisms regulating the levels of sexual steroids are activated by $90 \mathrm{~h}$ of exposure. ALP values on the average were lower in females than males and no response in $\mathrm{Vg}$ levels was detected in females after the exposure to E2 experimental concentrations. The results of this study do not answer the question of which processes are involved in the responses of $A$. ater to estrogen exposure, mainly due to the lack of information on the endocrine system of this bivalve. Nonetheless, this study stands out as a first approach to understanding how the endocrine system of this species may be affected by estrogen exposure. Our results suggest that the reproductive cycle A. ater may be altered by E2 exposure, which is relevant considering recent reports of high levels of E2 in the sediments off south-central Chile (Bertin et al. 2011).

\section{AcKnowledgments}

This research is part of the Programa de Investigación Marina de Excelencia (PIMEX) of the Faculty of Natural and Oceanographic Sciences of the Universidad de Concepción, funded by Celulosa Arauco and Constitución S.A. We wish to thank Jeanette Vera and Ana Jara for their support during the bioassays. The authors would like to thank two anonymous reviewers for their valuable comments and suggestions to improve the quality of the paper.

\footnotetext{
${ }^{1}$ Ortiz-Zaragoitia M \& MP Cajaraville. 2003. Application of novel techniques to assess effects of endocrine disruptors on reproduction of aquatic organisms. X Congreso de la Sociedad Española de Biología Celular, Santander.
} 


\section{LITERATURE CITED}

Aarab N, S Lemaire-Gony, E Unruh, PD Hansen, BK Larsen, OK Andersen \& JF Narbonne. 2006. Preliminary study of responses in mussel (Mytilus edulis) exposed to bisphenol A, diallyl phthalate and tetrabromodiphenyl ether. Aquatic Toxicology 788: S89-S92.

Aguirre-Martinez G, A Rudolph, R Ahumada, R Loyola \& V Medina. 2009. Toxicidad no específica en sedimentos portuarios, una aproximación al contenido de contaminantes críticos. Revista de Biología Marina y Oceanografía 44(3): 725-735.

Bertin A, PA Inostroza \& RA Quiñones. 2011. Estrogen pollution in a highly productive ecosystem off central-south Chile. Marine Pollution Bulletin 62: 1530-1537.

Blaise C, F Gagné, J Pellerin \& PD Hansen. 1999. Determination of vitellogenin-like properties in Mya arenaria hemolymph (Saguenay Fjord, Canada): a potential biomarker for endocrine disruption. Environmental Toxicology 14: 445-465.

Bradford MM. 1976. A sensitive method for the total protein determination using the principle of protein-dye binding. Analytical Biochemistry 72: 249-251.

Caliman FA \& M Gavrilescu. 2009. Pharmaceuticals, personal care products and endocrine disrupting agents in the environment-A review. Clean- Soil, Air, Water 37: 277-303.

Chen TS, T-C Chen, K-J Yeh, H-R Chao, E-T Liaw, Ch-Y Hsieh, K-Ch Chen, L-T Hsieh \& Y-L Yeh. 2010. High estrogen concentrations in receiving river discharge from a concentrated livestock feedlot. Science of the Total Environment 408: 3223-3230.

Ciocan CM, E Cubero-Leon, AM Puinean, EM Hill, Ch Minier, M Osada, K Fenlon \& JM Rotchell. 2010. Effects of estrogen exposure in mussel, Mytilus edulis, at different stages of gametogenesis. Environmental Pollution 158: 2977-2984.

Flouriot G, F Pakdel, B Ducouret \& Y Valotaire. 1995. Influence of xenobiotics on rainbow trout liver estrogen receptor and vitellogenin gene expression. Journal of Molecular Endocrinology 15: 143-151.

Gagnaire B, F Gagné, Ch André, Ch Blaise, K Abbaci, H Budzinski, M-H Dévier \& J Garric. 2009. Development of biomarkers of stress related to endocrine disruption in gastropods: Alkali-labile phosphates, protein- bound lipids and vitellogenin-like proteins. Aquatic Toxicology 92: 155167.

Gagné F, C Blaise, B Lachance, GI Sunahara \& H Sabik. 2001. Evidence of coprostanol etrogenicity to the freshwater mussel Elliptio complanata. Environmental Pollution 115: 97-106.

Gagné F, C Blaise, J Pellerin, E Pelletier, M Douville, S Gauthier-Clerc \& L Viglino. 2003. Sex alteration in softshell clams (Mya arenaria) in an intertidal zone of the Saint Lawrence River (Quebec, Canada). Comparative Biochemistry and Physiology, Part C 134: 189-198.
Gagné F, C Blaise \& J Hellou. 2004. Endocrine disruption and health effects of caged mussels, Elliptio complanata, placed downstream from a primary-treated municipal effluent plume for 1 year. Comparative Biochemistry and Physiology, Part C 138: 33-44.

Gagné F, C André \& C Blaise. 2005. Increased vitellogenin gene expression in the mussel Elliptio complanata exposed to estradiol-17 $\beta$. Fresenius Environmental Bulletin 14: 861866.

Gagné F, B Bouchard, C André, E Farcy \& M Fournier. 2010. Evidence of feminization in wild Elliptio complanata mussels in the receiving waters downstream of a municipal effluent outfall. Comparative Biochemistry and Physiology, Part C, <doi:10.1016/j.cbpc.2010.09.002>

Gagné F, B Bouchard, C André, E Farcy, M Fournier. 2011. Evidence of feminization in wild Elliptio complanata mussels in the receiving waters downstream of a municipal effluent outfall. Comparative Biochemistry and Physiology C, Toxicology and Pharmacology 153: 99-106.

Gauthier-Clerc S, J Pellerin \& JC Amiard. 2006. Estradiol$17 \beta$ and testosterone concentrations in male and female Mya arenaria (Mollusca, Bivalvia) during the reproductive cycle. General and Comparative Endocrinology 145: 133139.

Griffiths RJ. 1977. Reproductive cycles in littoral population of Choromytilus meridionalis ( $\mathrm{Kr}$ ) and Aulacomya ater (Molina) with a quantitative assessment of gamete production in the former. Journal of Experimental Marine Biology and Ecology 30: 53-71.

Hansen PD, H Dizer, B Hock, A Marx, J Sherry \& M Mcmaster. 1998. Vitellogenin-a biomarker for endocrine disruptors. Trends of Analytical Chemistry 17: 40-51.

Hashimoto S, H Bessho, A Hara, M Nakamura, T Iguchi, K Fujita. 2000. Elevated serum vitellogenin levels and gonadal abnormalities in wild male flounder (Pleuronectes yokohamae) from Tokyo Bay, Japan. Marine Environmental Research 49(1): 37-53.

Janer G. 2005. Steroid levels, steroid metabolic pathways and their modulation by endocrine disuprtors in invertebrates. $\mathrm{PhD}$ thesis, Universitat Autònoma de Barcelona, Barcelona, 268 pp. [on line] <http://hdl.handle.net/10803/3671>

Janer G, R Lavado, R Thibaut \& C Porte. 2004. Effects of $17 \beta$-estradiol exposure in the mussel Mytilus galloprovincialis. Marine Environmental Research 58(25): 443-446.

Janer G, R Lavado, R Thibaut \& C Porte. 2005. Effects of $17 \beta$-estradiol exposure in the mussel Mytilus galloprovincialis: A possible regulating role for steroid acyltransferases. Aquatic Toxicology 75: 32-42.

Jaramillo R \& J Navarro. 1995. Reproductive cycle of the Chilean ribbed mussel Aulacomya ater (Molina, 1782). Journal of Shellfish Research 14: 165-171. 
Ketata I, X Denier, A Hamza-Chaffai \& Ch Minier. 2008. Endocrine-related reproductive effects in molluscs. Comparative Biochemistry and Physiology, Part C 147: 261-270.

Lavado R, G Janer \& C Porte. 2006. Steroid levels and steroid metabolism in the Mussel Mytilus edulis: the modulating effect of dispersed crude oil and alkylphenols. Aquatic Toxicology 78: 65-72.

Lee LS, N Carmosini, SA Sassman, HM Dion \& MS Sepúlveda. 2007. Agricultural contributions of antimicrobials and hormones on soil and water quality. Advances in Agronomy 93: 1-69.

Li Q, M Osada, T Suzuki \& K Mori. 1998. Changes in vitellin during oogenesis an effect of estradiol on vitellogenesis in the Pacific oyster Crassostrea gigas. Invertebrate Reproduction and Development 33: 87-93.

Matozzo V \& MG Marin. 2005. Can 4-nonylphenol induce vitellogenin-like proteins in the clam Tapes philippinarum? Environmental Research 97: 43-49.

Matozzo V \& MG Marin. 2008. Can 17ß-estradiol induce vitellogenin-like proteins in the clam Tapes philippinarum? Environmental Toxicology and Pharmacology 26: 38-44.

Matozzo V, F Gagné, MG Marin, F Riccierdi \& Ch Blaise. 2008. Vitellogenin as a biomarker of exposure to estrogenic compounds in aquatic invertebrates: A review. Environmental International 34: 531-545.

Moura-Costa DD, F Filipak-Neto, MDM Costa, RN Morais, JRE Garcia, BM Esquivel \& CA Oliveira-Ribeiro. 2010. Vitellogenesis and other physiological responses induced by $17 \beta$-estradiol in males of freshwater sh Rhamdia quelen. Comparative Biochemistry and Physiology, Part C 151: 248-257.

Olavarría YA. 2007. Determinación de trazas de cadmio en cholga (Aulacomya ater), chorito (Mytilus chilensis) y ostra chilena (Ostrea chilensis) en la zona de Chiloé (Hueihue), 117 pp. Universidad Austral de Chile, Valdivia.

Ortiz-Zaragoitia M \& MP Cajaraville. 2006. Biomarkers of exposure and reproduction-related effects in mussels exposed to endocrine disruptors. Archives of Environmental Contamination and Toxicology 50: 361-369.

Palma M, F González, H Romo, E Ruiz \& C Fuentealba. 2007. Efectos de la contaminación sobre la diversidad genética de Mazzaella laminaroides (Bory) Fredericq (Gigartinales, Rhodophyta) en Bahías. Gayana Botanica 64: 24-32.

Pampanin DM, I Marangon, E Volpato, G Campesan \& C Nasci. 2005. Stress biomarkers and alkali-labile phosphate level in mussel (Mytilus galloprovincialis) collected in the urban area of Venice (Venice Lagoon, Italy). Environmental Pollution 136: 103-107.

Porte C, G Janer, LC Lorusso, M Ortiz-Zarragoitia, MP Cajaraville, MC Fossi \& L Canesi. 2006. Endocrine disruptors in marine organisms: Approaches and perspectives. Comparative Biochemistry and Physiology, Part C 143: 303-315.
Quinn B, F Gagné, M Costello, C Mckenzie, J Wilson \& C Mothersill. 2004. The endocrine disrupting effect of municipal effluent on the zebra mussel (Dreissena polymorpha). Aquatic Toxicology 66: 279-292.

Rudolph A, R Ahumada \& C Pérez. 2002. Dissolved oxygen content as an index of water quality in San Vicente Bay, Chile $\left(36^{\circ} 45^{\circ} \mathrm{S}\right)$. Environmental Monitoring Assessment 78: $89-100$.

Srain B \& A Rudolph. 2010. Acetylcholinesterase activity, antioxidant defenses, and lipid peroxidation in the clam Semele solida: Can this species be used as a bioindicator? Revista de Biología Marina y Oceanografía 45(2): 227-233.

Stanton MG. 1968. Colorimetric determination of inorganic phosphate in the presence of biological material and adenosine triphosphate. Analytical Biochemistry 22: 2734.

Suárez-Alonso P, C Álvarez-González, P García-Molist \& F San Juan-Serrano. 2007. Atresia gonadal durante el ciclo gametogénico de Mytilus galloprovincialis Lamarck, 1819 cultivado en la ría de Vigo (noroeste de la península Ibérica). Boletín del Instituto Español Oceanográfico 23: 3-10.

Thorpe KL, RI Cummings, TH Hutchinson, G Brighty, JP Sumpter \& ChR Tyler. 2003. Relative potencies and combination effects of steroidal estrogens in fish. Environmental Science Technology 37: 1142-1149.

Tremblay L \& G Van Der Kraak. 1998. Use of a series of homologous in vitro and in vivo assays to evaluate the endocrine modulating actions of $\beta$-sitosterol in rainbow trout. Aquatic Toxicology 43: 149-162.

Wallace RA. 1985. Vitellogenesis and oocyte growth in nonmammalian vertebrates. In: Browder LW (ed). Developmental biology: A comprehensive synthesis 1: 127177. Plenum Press, New York.

Wang S, W Huang, G Fang, Y Zhang \& H Qiao. 2008. Analysis of steroidal estrogen residues in food and environmental samples. International Journal of Environmental Analytical Chemistry 88: 1-25.

Welshons WV, KA Thayer, BM Judy, JA Taylor, EM Curran \& FS Vom Saal. 2003. Large effects from small exposures. I. Mechanisms for endocrine-disrupting chemicals with estrogenic activity. Environmental Health Perspectives 111: 994-1006.

Welshons WV, S Nagel \& FS Vom Saal. 2006. Large effects from small exposures. III. endocrine mechanisms mediating effects of bisphenol A at levels of human exposure. Endocrinology 147(Suppl): 56-69.

Weltje L, FS Vom Saal \& J Oehlmann. 2005. Reproductive stimulation by low doses of xenoestrogens contrasts with the view of hormesis as an adaptative response. Human Experimental Toxicology 24: 431-437.

Wester PW, LTM Van der Ven \& JG Vos. 2004. Comparative toxicological pathology in mammals and fish: some examples with endocrine disrupters. Toxicology 205: 27-32.

Received 1 June 2012 and accepted 19 October 2012

Associate Editor: Claudia Bustos D. 